\title{
Sport Supplementation: Review Of Performance Enchasing Dietary Supplements Used In Sport
}

\author{
Gergina Peteva \\ Valentin Ivanov
}

Medical University Plovdiv, Faculty of Medicine, Plovdiv, Bulgaria

doi: 10.19044/esj.2016.v12n18p14 URL:http://dx.doi.org/10.19044/esj.2016.v12n18p14

\begin{abstract}
Performance enchasing substances have been used since ancient times in different sport disciplines and in all level of competition. Performance enchasing substances could be illicit drugs, prescription medicines (like Anabolic steroids) or dietary supplements as amino acids and vitamins. In this review we have summarised the benefits and the risks of supplementation in sport with different categories food additives. We have divided these products in following categories: food additives containing amino acids, food additives containing Tribulus Terrestris extract, containing Yohimbine, Dehydroepiandrosterone (DHEA), Vitamin E and Creatine.
\end{abstract}

Keywords: DHEA, sport, food additives, dietary supplements

\section{Introduction}

Performance enchasing drugs have been used since ancient times in different sport disciplines and in all level of competition. In 1999 World Anti Doping Agency has been established to create a doping-free sporting environment. The Agency consists of equal representatives from the Olympic Movement and public authorities. (WADA, 2016) There are several hundred forms of known and potentially more unknown doping substances and techniques abused by professional athletes worldwide. (Baron, 2007) Doping in sport is now a global problem that follows international sporting events worldwide. (Baron, 2007) For the past 50 years anabolic-androgenic steroids have been used by a wide variety of people (Ivanova, 2014) for nonmedical purpose. Anabolic androgenic steroids are often used by professional and nonprofessional athletes as doping. Anabolic steroid abuse can be associated with a wide range of adverse side effects ranging from some that are physically unattractive, such as acne and breast development in men, to others that are life threatening, such as heart attacks and liver cancer. Most are reversible if the abuser stops taking the drugs, but some are 
permanent, such as voice deepening in females. Steroid abuse disrupts the normal production of hormones in the body, causing both reversible and irreversible changes. Changes that can be reversed include reduced sperm production and testicular atrophy. Irreversible changes include male-pattern baldness and breast development (gynecomastia) in men. (Ivanova, 2014) The proportion benefit - risk shows that any kind of abuse with AAS drugs is extremely dangerous. (Ivanova, 2014) Supplementation with natural food additives with animal or plant origin also could improve sport performance. Many athletes use amino acids, Vitamins, DHEA and other food additives to achieve better results in sport. Performance enchasing food additives are safer than AAS and the consumption of these products is growing. Almost all people who practice some kind of sport use one or another kind of food additive to achieve better and faster results. Nowadays there is a big demand of food supplements with androgenic effects (Ivanova, 2014) and hight performance-enchasing potential in sport.

\section{Performance enhancing supplementation}

Performance-enhancing substances include dietary supplements, prescription medications, and illicit drugs. (American Academy, 2005) For athletes of all ages, the pursuit of excellence in sports is essential. Success in sports involves obtaining an "edge" over the competition. However, sometimes the drive for success can be so engrossing and so compelling that a young person can easily lose sight of what is fair and right. Some individuals may view the use of performance-enhancing substances as a substitute for hard work. For others, performance-enhancing substances may be considered a necessary adjunct to hard work or part of the price of success. From the user's perspective, the prospects for success in sports often outweigh the prospects for serious medical complications from use of performance-enhancing substances. (American Academy, 2005) In this article we have reviewed only the dietary supplements with hight performance potential used in sport. We have divided these products in following categories: food additives containing amino acids, food additives containing Tribulus Terrestris extract, containing Yohimbine, Dehydroepiandrosterone (DHEA), Vitamin E and Creatine. Table 1 demonstrates most used categories food supplements in sport. 
Table 1. Most used food supplements in sport

\begin{tabular}{|c|c|c|c|c|c|}
\hline $\begin{array}{l}\text { Dietary } \\
\text { supple- } \\
\text { ments }\end{array}$ & $\begin{array}{c}\text { Benefits of } \\
\text { supplementation } \\
\text { in sport aspect }\end{array}$ & $\begin{array}{l}\text { Other benefits } \\
\text { for human } \\
\text { health }\end{array}$ & $\begin{array}{l}\text { Prohibited } \\
\text { substance } \\
\text { by World } \\
\text { Anti } \\
\text { Doping } \\
\text { Agency }\end{array}$ & $\begin{array}{l}\text { Contra- } \\
\text { indications }\end{array}$ & Ref. \\
\hline $\begin{array}{l}\text { Protein } \\
\text { products } \\
\text { and Amino } \\
\text { acids }\end{array}$ & $\begin{array}{l}\text { Increase } \\
\text { endurance, help } \\
\text { growth of } \\
\text { muscles tissues, } \\
\text { reduce fatigue, } \\
\text { improve } \\
\text { recovery after } \\
\text { exercise. }\end{array}$ & $\begin{array}{l}\text { L-arginine is } \\
\text { one of the most } \\
\text { effective food } \\
\text { supplements for } \\
\text { the treatment of } \\
\text { erectile } \\
\text { dysfunction. }\end{array}$ & No & No & (Ivanova 2014) \\
\hline $\begin{array}{l}\text { Tribulus } \\
\text { terrestris } \\
\text { extract }\end{array}$ & $\begin{array}{c}\text { Increase } \\
\text { testosterone } \\
\text { levels. } \\
\text { Help growth of } \\
\text { muscles tissues, } \\
\text { reduce fatigue, } \\
\text { improve } \\
\text { recovery after } \\
\text { exercise }\end{array}$ & $\begin{array}{c}\text { Antibacterial } \\
\text { action, } \\
\text { antifungal } \\
\text { action, } \\
\text { antihelmintic } \\
\text { action, analgesic } \\
\text { action, } \\
\text { antihypertensive } \\
\text { action, diuretic } \\
\text { action, } \\
\text { hypoglycemic } \\
\text { action, } \\
\text { hypolipidemic } \\
\text { and cytotoxic } \\
\text { action }\end{array}$ & No & No & $\begin{array}{c}\text { (Oh,2011) } \\
\text { (Al- } \\
\text { Bayati,2008) } \\
\text { (Zhang,2006) } \\
\text { (Deepak,2002) } \\
\text { (Heidari,2007) } \\
\text { (Sharifi,2003) } \\
\text { (Nalwaya,2009) } \\
\text { (Li,2002) } \\
\text { (Chu, 2014) } \\
\text { (Ivanova,2014) }\end{array}$ \\
\hline Yohimbine & $\begin{array}{l}\text { Increase } \\
\text { testosterone } \\
\text { levels. } \\
\text { Help growth of } \\
\text { muscles tissues, } \\
\text { reduce fatigue, } \\
\text { improve } \\
\text { recovery after } \\
\text { exercise }\end{array}$ & $\begin{array}{l}\text { Successfully } \\
\text { used for } \\
\text { treatment of } \\
\text { erectile } \\
\text { dysfunction. }\end{array}$ & No & $\begin{array}{l}\text { The therapeutic } \\
\text { index of } \\
\text { Yohimbine is } \\
\text { quite } \\
\text { low.Yohimbine } \\
\text { should not be } \\
\text { consumed by } \\
\text { anyone with } \\
\text { liver, kidney, } \\
\text { heart disease or } \\
\text { a psychological } \\
\text { disorder. }\end{array}$ & (Ivanova,2014) \\
\hline $\begin{array}{l}\text { Vitamine } \\
\text { E }\end{array}$ & $\begin{array}{c}\text { Prevent } \\
\text { exercise- } \\
\text { induced } \\
\text { oxidative } \\
\text { damage. }\end{array}$ & $\begin{array}{l}\text { Anti oxydant } \\
\text { action. } \\
\text { Vitamin E is } \\
\text { important for } \\
\text { normal } \\
\text { neurological } \\
\text { function. }\end{array}$ & No & No & (Ivanova,2015) \\
\hline Creatine & $\begin{array}{l}\text { Improve high- } \\
\text { intensity }\end{array}$ & No & No & $\begin{array}{l}\text { There are } \\
\text { reports of }\end{array}$ & (Ivanova,2015) \\
\hline
\end{tabular}




\begin{tabular}{|c|c|c|c|c|c|}
\hline & $\begin{array}{c}\text { exercise, } \\
\text { intermittent } \\
\text { high-intensity } \\
\text { exercise, and } \\
\text { even endurance } \\
\text { exercise } \\
\text { (mainly in non- } \\
\text { weight-bearing } \\
\text { endurance } \\
\text { activities). } \\
\text { Improve muscle } \\
\text { strength. }\end{array}$ & & & $\begin{array}{l}\text { kidney damage } \\
\text { with creatine } \\
\text { use, such as } \\
\text { interstitial } \\
\text { nephritis. } \\
\text { Patients with } \\
\text { kidney disease } \\
\text { should avoid } \\
\text { use of this } \\
\text { supplement. }\end{array}$ & \\
\hline DHEA & $\begin{array}{l}\text { Regulation of } \\
\text { hormonal } \\
\text { levels. Increase } \\
\text { muscle strength. } \\
\text { Hight } \\
\text { performance- } \\
\text { enchasing } \\
\text { potential. }\end{array}$ & $\begin{array}{l}\text { Supplementation } \\
\text { with DHEA give } \\
\text { many benefits in } \\
\text { hormone } \\
\text { replacement } \\
\text { therapy in } \\
\text { patients with } \\
\text { low endogenous } \\
\text { DHEA and } \\
\text { DHEAS. }\end{array}$ & $\begin{array}{c}\text { Yes. } \\
\text { Class S1 }\end{array}$ & No & (WADA,2016) \\
\hline
\end{tabular}

\section{Protein and Amino acids supplementation}

Protein is one of the most popular dietary supplements marketed to athletes and physically-active individuals. Protein supplements have been recommended to athletes to enhance nitrogen retention and increase muscle mass, to prevent protein catabolism during prolonged exercise, to promote muscle glycogen resynthesis following exercise, and to prevent sports anemia by promoting an increased synthesis of hemoglobin, myoglobin, oxidative enzymes, and mitochondria during aerobic training. However, whether or not athletes need more protein is currently debatable. Based on available research, the American College of Sports Medicine, the American Dietetic Association, and the Dietitians of Canada, in their recent joint position stand on nutrition and athletic performance (American Dietetic,2000), (Williams,2005), concluded that protein requirements are higher in very active individuals and suggested that resistance athletes need 1.6-1.7 g protein $/ \mathrm{kg}$ body weight while endurance athletes need approximately $1.2-1.4 \mathrm{~g}$ protein $/ \mathrm{kg}$, values that are about $150-200$ percent of the current United States Recommended Dietary Allowances (RDA). (Williams,2005) However, dietary protein is composed of 20 different amino acids which, if ingested individually, have been theorized to possess ergogenic potential and have been marketed as sports supplements to physically active individuals. Indeed, amino acids are among the top five most popular sports supplements. (Williams,2005), (Lawrence, 2002) 
Amino acids are biologically important organic compounds that contain amine and carboxylic acid functional groups, along with a side-chain specific to each amino acid. Amino acids can be divided to two types, essential and non-essential. Eight amino acids have been found necessary and essential. The amino acids have a biological activity and are components in foods and food additives. The foods and food additives contain a different variety of essential and non-essential amino acids that play a critical role in metabolizing nutrients, building muscle tissue, and protecting the body against disease. (Ivanov, 2014)

Amino acids are theorized to enhance performance in a variety of ways, such as increasing the secretion of anabolic hormones, modifying fuel use during exercise, preventing adverse effects of overtraining, and preventing mental fatigue.(Williams, 2005) Glutamine may be theorized to be ergogenic in various ways. (Williams, 2005) Tryptophan supplementation increase serotonin production in attempts to increase tolerance to pain during intense exercise. (Williams, 2005) Glutamine is often called "an important fuel" for cells of the immune system, such as lymphocytes and macrophages, which may be decreased with prolonged intense exercise, such as that related to overtraining. Glutamine may also promote muscle glycogen synthesis, and has been studied for potential enhancement of muscular strength. (Williams,2005) Arginine supplementation increases endurance capacity. Ornithine, lysine and arginine have been used in attempts to increase human growth hormone (HGH) production, the theory being to increase lean muscle mass and strength. (Williams, 2005) Taurine is a nonessential sulfur-containing amino but it plays a role in some important metabolic processes, such as heart contraction and also has a hight antioxidant activity.Taurine is an ingredient in many energy drinks. Researchers indicate that consumption of a about 0.1 gram of essential amino acids per kilogram of body weight ( 7 grams for a 70-kilogram athlete) during the first few hours of recovery from heavy resistance exercise will produce a transient, net positive increase in muscle protein balance. (Williams, 2005), (Tipton, 1998)

\section{Tribulus Terrestris supplementation}

Tribulus terrestris (TT) is an annual plant in the caltrop family (Zygophyllaceae) widely distributed around the world, that is adapted to grow in dry climate locations in which few other plants can survive. (Flowering plants, 2000) Tribulus terrestris extracts have been used for centuries all over the World (especially Europe, Africa, India) - it has been regarded as an aphrodisiac in addition to its beneficial claims on various ailments such as urinary infections, inflammations, oedema and ascites. (Ivanova, 2016) Recent scientific studies indicate that Tribulus 
terrestris extract helps to support healthy hormone production and male reproductive health. Trebles terrestrial extract demonstrates a hight antioxidant potential. Tribulus supplementation is used by many professional and non professional athletes for achieve better and faster results. The extract of this herb stimulates the production of luteinizing hormone, which directly affects the production of testosterone. Increased testosterone levels increase strength, muscle growth, prolongerection and potency. Preparations based on the saponin fraction of TT are used for treatment of infertility and libido disorders in men and women, as well as for treatment of cardiac diseases. FA and OTC products, containing TT improvemuscle growth and body strength, increasethe number and motility of spermatozoidsand the body's natural testosterone levels, help in alleviating some symptoms associated with male menopause. (Ivanova, 2015) The beneficial effects in sport of this herbal extract is due to the steroidal saponins. Some of the main saponins, isolated from TT extract are: tigogenin, neotigogenin, gitogenin, neogitogenin, hecogenin, neohecogenin, diosgenin, chlorogenin, ruscogenin,sarsasapogenin, protodioscin. (Ivanova, 2015)

\section{Yohimbine supplementation}

Food additives containing Yohimbine are considered to possess androgenic effects and hight performance-enchasing potential. Yohimbine, the major alkaloid of Yohimbe bark, is used as active ingredients in a number of medicinal products. As a stimulant, yohimbine increase also fat metabolism. Yohimbine supplementation appears to be suitable as a fat loss strategy in professional and non professional athletes. (Ostojic,2006) Even Yohimbine containing products are sold as dietary supplements in the most part of the World, these products could be dangerous for people with cardiovascular disease or other cardio-vascular problems. Yohimbe supplementation should be done under the supervision of a doctor. Yohimbine supplementation can cause many adverse effects as headache, nausea, increased urinary urge, insomnia, anxiety, restlessness, irritability, increase of blood pressure and pulse rate, palpitation, dizziness, vomiting, anorexia, gastric complaints, diarrhoea, flush, sweating, shivering, allergic reactions, hypotension, tremor, bronchospasm, dysuria, decreased urge, genital pains, exanthema. (Ivanova, 2014)

\section{DHEA supplementation}

Dehydroepiandrosterone, also known as androstenolone or prasterone is an important endogenous steroid hormone. (Ivanova, 2015), (Mo,2008) DHEA (dehydroepiandrosterone) was first isolated in 1934 from urine by Butenandt and Dannenbaum. In 1944, Dehydroepiandrosterone sulfate 
(DHEA-S), DHEA's sulfated metabolite, was isolated from the urine. In 1954, DHEA was isolated from the blood, and in 1959 the chemist E. Baulieu discovered that DHEA-S, which is the most abundant form of the hormone found in human plasma. (Ivanova, 2015) DHEA is a weak androgen that needs conversion to more potent testosterone, and the assumption is that athletes expect a significant increase in circulating testosterone through exogenous DHEA administration, with a subsequent improvement in performance. (Collomp, 2015) Because of the hight performance-enchasing potential of DHEA WADA (World Anti Doping Agency) considered this substance as doping. DHEA is included in the Prohibited List. It is forbidden substance for professional athletes. It is generally accepted in the sporting world that dehydroepiandrosterone (DHEA) use enhances physical performance, and DHEA therefore figures on the World Anti-Doping Agency (WADA) list of prohibited substances in sports, both in and out of competition.[29]Undoubtedly the intake of DHEA gives benefits but to put a definitive evaluation are needed more specific studies. The researches show that DHEA may have a role in hormone replacement therapy in patients with low endogenous DHEA and DHEAS. Many clinical trials suggest that doses of 30-50mg of oral DHEA may produce physiologic androgen levels. These studies report a dose-dependent effect and lack of accumulation of serum androgen levels. These studies also reveal a gender-specific response to DHEA therapy such that testosterone levels are increased in women but not in men. The trials show that supplementation with Prasterone restores Dehydroepiandrosterone sulfate serum concentrations to the normal range for young adults (aged 20-50 years). Although the DHEA supplementation is well widely practiced by athletes, the trials have consistently shown that DHEA supplementation does not increase statistically significant testosterone levels, enhance muscle mass or muscle strength. The DHEA supplementation gives improvement in short physical performances. The conditions in which Dehydroepiandrosterone could preserve or improve muscle strength and morphological features still need to be determined and more clinical studies are needed. (Ivanova, 2015)

\section{Conclusion}

Undoubtedly the intake of Amino acids, Tribulus Terrestris, Yohimbine,Vitamin E, Creatine and DHEA give many benefits but to put a definitive evaluation are needed more specific scientific studies. These products are widely used by professional and non professional athletes all over the world. The researches show that Amino acids, Tribulus Terrestris extract, Yohimbine,Vitamin E, Creatine and DHEA have not only performance enchasing potential but also have many beneficial effects on human health. The conditions in which Dehydroepiandrosterone, Tribulus 
terrestris extract and Yohimbine could improve muscle strength and morphological features still need to be determined and more clinical studies are needed.

\section{References:}

Baron D, Martin D, Magd S, Doping in sports and its spread to at-risk populations: an international review, World Psychiatry. 2007 Jun; 6(2): 118123.

https://www.wada-ama.org/en/who-we-are, reached may 2016

Ivanova S, Ivanov K, Pankova S, Peikova L. Consenquences of anabolic steroids abuse, Pharmacia, 2014, 61(4)

Stanislava Ivanova, Stefka Pankova, Valentina Petkova, Milen Dimitrov, Food additives with beneficial effects in the treatment of erectile dysfunction, containing L-arginine, Pycnogenol and ginseng extract, World journal of pharmacy and pharmaceutical sciences,2014, 3 (11), 234-245.

Oh H-K, Park SJ, Moon HD, Jun SH, Choi N-Y, You Y-O. Tribulus terrestris inhibits caries- inducing properties of Streptococcus mutans. J Med Plants Res 2011; 5(25): 6061-6066.

Al-Bayati, FA, Al-Mola HF. Antibacterial and antifungal activities of different parts of Tribulus terrestris L. growing in Iraq. J Zhejiang Uni Sci B 2008; 9(2): 154-159.

Zhang JD, Xu Z, Cao YB, Chen HS, Yan L, An MM, Gao PH, Wang Y, Jia XM, Jiang YY. Antifungal activities and action mechanisms of compounds from Tribulus terrestris L. J Ethnopharmacol 2006; 103(1): 76-84

Deepak M, Dipankar G, Prasanth D, Asha MK, Amit A, Venkatraman BV. Tribulosin and $\beta$-sitosterol-D-glucoside, the anthelmintic prin- ciples of Tribulus terrestris. Phytomedicine 2002; 9(8): 753-756.

Heidari MR, Mehrabani M, Pardakhty A, Khazaeli P, Zahedi MJ, Yakhchali M, Vahedian M. The analgesic effect of Tribulus terrestris extract and comparison of gastric ulcerogenic- ity of the extract with indomethacine in animal experiments, Ann N Y Acad Sci 2007; (1095): 418-427.

Sharifi AM, Darabi R, Akbarloo N. Study of antihypertensive mechanism of Tribulus ter- restris in 2K1C hypertensive rats: role of tissue ACE activity. Life Sci. 2003; 73(23): 2963-2971.

Nalwaya N, Jarald EE,Asghar S,Ahmad S. Diuretic activity of a herbal product UNEX. Int J Green Pharm 2009; 3(3): 224-226.

Li M, QuW,WangY,WanH,TianC.Hy- poglycemic effect of saponin from Tribulus ter- restris. Zhong Yao Cai, 2002; 25(6): 420-422.

Chu S,QuW,PangX,SunB,HuangX.Effect of saponin from Tribulus terrestris on hyperlipi- demia. Zhong Yao Cai, 2003; 26(5): 341-344. 
Ivanova S, Obreshkova D, Ivanov K, Atanasov P, Zlatkov B. Investigation of some food additives containing compounds with androgenic activity and their analytical study, Pharmacia, 2014 , 61(3).

Ivanova S, Ivanov K, Pankova S, Zlatkov B, Stoychev K. Sport supplementation: beneficial effects of vitamin $\mathrm{E}$ and Creatine on exercise performance. Pharmacia, 2015; 62(2) : 40-49.

http://www.mayoclinic.org/drugs-supplements/creatine/safety/hrb-20059125, reached may 2016

Takanami Y, Iwane H, Kawai Y, Shimomitsu T, Vitamin E supplementation and endurance exercise: are there benefits?,Sports Med., 2000 Feb;29(2):7383.

American academy of pediatrics, policy statement,Organizational Principles to Guide and Define the Child Health Care System and/or Improve the Health of All Children,Committee on Sports Medicine and Fitness,Use of Performance-Enhancing Substances, April 2005,115(4)

American Dietetic Association, Dietitians of Canada American College of Sports Medicine. Nutrition and athletic performance. Journal of the American Dietetic Association. 2000;100:1543-46.

Williams M, Dietary Supplements and Sports Performance: Amino Acids, J Int Soc Sports Nutr. 2005; 2(2): 63-67.

Lawrence M, Kirby D. Nutrition and sports supplements: Fact or fiction. Journal of Clinical Gastroenterology. 2002;35:299-306. doi: 10.1097/00004836-200210000-00005.

Williams MH. Nutrition for Health, Fitness \& Sports. Boston: McGraw-Hill; 2005.

Tipton K, Wolfe R. Exercise-induced changes in protein metabolism. Acta Physiological Scandinavica. 1998;162:377-87. doi: 10.1046/j.1365201X.1998.00306.x.

Flowering Plants of the Santa Monica Mountains, Nancy Dale, 2nd Ed., 2000, p. 200

Ivanova Stanislava, Ivanov K, Mladenov R, Papanov S, Ivanova S, Obreshkova D, Atanasov P, Petkova V, Food supplements with anabolic and androgenic activity - UHPLC analysis of food additives, containing Tribulus terrestris extract, World Journal of Pharmaceutical Research,2016, 5 (3), 613

Ostojic SM, Yohimbine: the effects on body composition and exercise performance in soccer players., Res Sports Med. 2006 Oct-Dec;14(4):28999.

Ivanova S, Ivanova S, Ivanov K, Obreshkova D, Papanov S. The effects of treatment with Prasterone (DHEA) on circulating hormones, body composition and muscle strength in men and women. Pharmacia, 2015 ,61 (4),36-43 
M o Q, Lu SF, Simon NG, Dehydroepiandrosterone and its metabolites: differential effects on androgen receptor trafficking and transcriptional activity,J. Steroid Biochem. Mol. Biol, 2006 Apr; 99(1):50-8

Pr. K. Collomp, Pr. Do, Prof. Lasne, "Exogenous DHEA administration and performance: Possible mechanisms of action and metabolic signature”, 2015, https://www.wada-ama.org/en/resources/exogenous-dhea-administrationand-performance-possible-mechanisms-of-action-and-metabolic, reached May 2016.

Ivanov K, Georgieva M, Atanasov P, Ivanova S. Production and regulatory analytical control of amino acids include in food additives, Pharmacia, 2014, 61(2). 